\title{
Komparasi Penggunaan Modul Cetak dengan Multimedia Interaktif Terhadap Hasil Belajar Ditinjau dari Kreativitas Siswa
}

\author{
Reni Fitrisia $^{1,2 *}$ dan Nizwardi Janlinus ${ }^{2}$ \\ ${ }^{1}$ SMK N 2 Bukittinggi \\ ${ }^{2}$ Program Studi Magister Pendidikan Teknologi Kejuruan, Fakultas Teknik, Universitas Negeri Padang \\ *Corresponding author, e-mail: rfitrisia@gmail.com
}

\begin{abstract}
Abstrak - Penelitian ini bertujuan untuk membandingkan hasil belajar Keterampilan Komputer dan Pengelolaan Informasi (KKPI) siswa kelas XI yang menggunakan multimedia interaktif dengan yang menggunakan modul cetak ditinjau dari kreativitas di SMK N 2 Bukittinggi. Penelitian ini menggunakan metode eksperimen semu dengan sampel satu kelas eksperimen dan satu kelas kontrol yang dipilih dengan teknik cluster porpusive sampling. Data kreativitas siswa diperoleh dengan menggunakan Torrance Tests of Creative Thinking (TTCT). Hasil penelitian dianalisis menggunakan analisis varian dua arah dan uji t. Hasil penelitian menunjukkan bahwa : 1) hasil belajar siswa yang menggunakan multimedia interaktif lebih baik dibandingkan dengan yang menggunakan modul cetak, 2) hasil belajar siswa berkreativitas tinggi yang menggunakan multimedia interaktif lebih baik dibandingkan siswa berkreativitas tinggi yang menggunakan modul 3) hasil belajar siswa berkreativitas rendah yang menggunakan multimedia interaktif juga lebih baik dibandingkan siswa berkreativitas rendah yang menggunakan modul cetak, dan 4) terdapat interaksi antara strategi pembelajaran yang menggunakan multimedia interaktif atau modul cetak dengan kreativitas siswa dalam mempengaruhi hasil belajar KKPI siswa kelas XI di SMK N 2 Bukittinggi.
\end{abstract}

Kata Kunci : hasil belajar, kreativitas, multimedia interakif

\begin{abstract}
This research aimed to compare the students achievement in the Computer Skill and Information Management subject for class XI students based on using Interactive Multimedia versus Printed Module only based on students level of creativity in SMKN 2 Bukittinggi. The quasi experimental method was used with one experiment class and one control class, which is selected with cluster porpusive sampling method. Creativity test was conducted earlier to decide the low and the high creative students by Torrance Tests of Creative Thinking (TTCT). Two way analysis of variance methods and test were used in data analyses. The research results shows that 1 ) the students achievement using interactive multimedia is better than the using printed module only, 2) the students achievement for the high creativity students using interactive multimedia was better than the high creativity students that using printed module only, 3) the students achievement for the low creativity students using interactive multimedia was better than the students achievement using printed module only, and 4) there was an interaction between using interactive multimedia versus printed module with student's level creativity in influencing the students achievement.
\end{abstract}

Keywords : learning outcomes, creativity, interactive multimedia

This is an open access article distributed under the Creative Commons 4.0 Attribution License

\section{Pendahuluan}

Ketercapaian kompetensi pelajaran KKPI yang dikuasai siswa dapat dilihat dari hasil belajar siswa tersebut. Hasil belajar siswa pada hakikatnya adalah perubahan tingkah laku dan sebagai umpan balik dalam upaya memperbaiki proses belajar mengajar [1]. Data hasil belajar KKPI siswa kelas XI di SMK N 2 Bukittinggi yang diperoleh dilapangan menunjukkan bahwa masih ada hasil belajar siswa yang belum mencapai Kriteria 
Ketuntasan Minimal (KKM). Perbedaan hasil belajar siswa ini dipengaruhi oleh beberapa faktor, . yaitu : faktor internal, faktor eksternal dan faktor pendekatan belajar[2]. Berdasarkan pengamatan yang dilakukan selama proses pembelajaran, diduga ada beberapa kemungkinan yang menyebabkan beberapa orang siswa yang hasil belajarnya tidak mencapai KKM, yaitu: 1) faktor internal siswa dan 2) pendekatan pembelajaran yang kurang tepat.

Faktor internal siswa berkaitan dengan kondisi psikologis siswa yang berbeda-beda, yang mencakup bakat, minat, motivasi, emosi, kreativitas dan kemampuan kognitif. Faktor internal yang diamati dalam penelitian ini adalah faktor kreativitas. Variabel kreativitas dipilih karena karakteristik pelajaran KKPI yang berhubungan erat dengan perkembangan teknologi informasi yang pesat dan dinamis, sehingga menuntut kreativitas siswa dalam belajar. Kreativitas adalah kemampuan untuk membuat kombinasi baru, berdasarkan data, informasi atau unsur-unsur yang ada dimana hasil yang diciptakan tidak selalu hal-hal yang baru, tetapi juga dapat berupa gabungan dari hal-hal yang sudah ada sebelumnya [3].Secara umum, kreativitas siswa dapat dikelompokan atas kreativitas kognitif (aptitude) dan kreativitas sikap atau perasaan (nonaptitude) [3]. Kreativitas kognitif atau disebut juga kemampuan berpikir kreatif meliputi : keterampilan berpikir lancar, berpikir luwes, berpikir orisinal dan keterampilan memerinci. Sedangkan kreativitas sikap meliputi : rasa ingin tahu, sifat imajinatif, merasa tertantang oleh kemajemukan, sifat berani mengambil resiko dan sifat menghargai.

Kreativitas siswa yang diukur dalam penelitian ini adalah kemampuan berpikir kreatif. Salah satu instrumen yang dapat digunakan untuk mengukur ciri-ciri kreativitas kognitif adalah Torrance Tests of Creative Thinking (TTCT), yang merupakan salah satu bentuk baku tes berpikir kreatif yang sederhana serta memiliki validitas dan reliabilitas yang tinggi [4-5].

Kreativitas siswa dipengaruhi oleh dorongan dari dalam diri sendiri dan dorongan dari luar. Faktor yang mempengaruhi kreativitas siswa yang berhubungan dengan dorongan dari luar salah satunya adalah strategi pembelajaran. Guru dituntut melaksanakan pembelajaran yang dapat meningkatkan kreativitas siswa. Hal ini berkaitan erat dengan dugaan tentang faktor kedua yang mempengaruhi hasil belajar, yaitu pendekatan pembelajaran yang kurang tepat.
Pendekatan pembelajaran meliputi strategi, model dan metode yang digunakan guru dalam pembelajaran. Pengamatan di lapangan menunjukkan bahwa pelajaran KKPI di SMKN 2 Bukittinggi dilaksanakan dengan menggunakan modul cetak. Berdasarkan pengamatan selama proses pembelajaran, penggunaan modul belum sepenuhnya mampu meningkatkan kemandirian dan kreativitas siswa. Indikator ini terlihat seperti : hanya sebagian siswa yang mampu memahami materi dalam modul secara mandiri sedangkan sebagian lain masih membutuhkan bimbingan dari guru, siswa belum familiar dengan istilah-istilah dalam modul sehingga mengalami kesulitan belajar mandiri dan ide-ide kreatif siswa dalam mengerjakan latihan masih rendah sementara karakteristik materi KKPI yang dinamis menuntut kreativitas siswa dalam menyelesaikan latihan yang diberikan.

Materi pelajaran KKPI yang lebih banyak berisikan praktek menggunakan komputer membuat sebagian siswa agak sulit melaksanakan praktek secara mandiri dengan bantuan modul. Hal ini disebabkan oleh isi modul itu sendiri yang hanya berupa teks dan gambar. Siswa akan lebih mudah memahami materi secara mandiri jika bahan ajar disajikan dalam bentuk demontrasi dan tutorial, sesuai dengan teori kerucut pengalaman Edgar Dahle (Edgar Dahle cone of experience) yang mengungkapkan bahwa pengalaman belajar siswa yang menggunakan media yang hanya bisa dibaca dan dilihat lebih rendah dibandingkan dengan pengalaman belajar siswa yang menggunakan media yang bisa dilihat dan didengar [6].

Berdasarkan teori kerucut pengalaman Edgar Dahle, hasil belajar KKPI dapat ditingkatkan dengan menggunakan bahan ajar yang dapat didengar, dibaca dan dilihat oleh siswa, seperti dalam bentuk multimedia interaktif. Desain multimedia yang menarik dan interaktif dalam pembelajaran KKPI dapat meningkatkan krativitas siswa dalam belajar, sehingga hasil belajar menjadi lebih baik dibanding menggunakan modul cetak. Hal ini sesuai dengan kesimpulan peneliti sebelumnya yang menyatakan bahwa hasil belajar siswa yang menggunakan multimedia interaktif lebih tinggi dibandingkan dengan yang menggunakan modul cetak [7].

Multimedia interaktif dapat dibuat dalam beberapa bentuk, salah satunya adalah CD (Compact Disk), yang merupakan CD program pembelajaran yang mencakup berbagai sumber yang terintegrasi dalam perintah-perintah dalam sebuah sistem berbasis computer [8][9]. 
Berdasarkan pengamatan di lapangan, SMKN 2 Bukittinggi memiliki fasilitas yang memadai untuk melaksanakan pembelajaran menggunakan multimedia interaktif. Hal ini terlihat dari fasilitas yang dimiliki, seperti laboratorium komputer sebanyak 5 labor di mana setiap komputer sudah dilengkapi cd room.

Berdasarkan keunggulan multimedia interaktif ini, maka dilakukan eksperimen untuk meningkatkan hasil belajar KKPI siswa dengan menggunakan multimedia interaktif. Untuk melihat efektifitas penggunaan multimedia interaktif dalam meningkatkan hasil belajar siswa, maka hasil eksperimen dibandingkan dengan hasil belajar siswa yang menggunakan modul cetak ditinjau dari kreativitas siswa.

\section{A. Pembelajaran dengan Modul Cetak}

Modul adalah sebuah bahan ajar yang disusun secara sistematis dengan bahasa yang mudah dipahami oleh peserta didik sesuai tingkat pengetahuan dan usia mereka, agar mereka dapat belajar sendiri (mandiri) dengan bantuan atau bimbingan yang minimal dari pendidik [10]. Modul memungkinkan siswa dapat menyelesaikan bahan belajarnya secara mandiri serta dapat menilai kemajuannya sendiri, sehingga hasil belajar selalu dapat diketahui.

Tujuan pembelajaran dengan modul adalah untuk meningkatkan keaktifan siswa dalam belajar. Agar tujuan pembelajaran dengan modul tercapai, maka modul yang baik harus memiliki karakteristik self instructional, self contained, stand alone (berdiri sendiri), adaptif, dan user friendly [11]. Modul yang baik memungkinkan siswa untuk membelajarkan diri sendiri, tidak bergantung pada pihak lain, memuat seluruh materi yang dibutuhkan dalam topik yang dibahas serta mudah digunakan, sehingga bersahabat dengan penggunanya. Modul yang baik memiliki komponen pedoman guru, lembar kegiatan siswa, lembar kerja, kunci lembar kerja, lembar tes dan kunci lembar tes.

Pembelajaran dengan modul cetak yang baik dilakukan dengan beberapa langkah berikut : 1) Modul dibagikan kepada siswa paling lambat seminggu sebelum pembelajaran, 2) Penerapan modul dalam pembelajaran menggunakan metode diskusi model pembelajaran kooperatif konstruktivistik, 3) Pada setiap akhir unit pembelajaran dilakukan tes dan tugas-tugas latihan yang terstruktur, 4) Hasil tes dan tugas yang dikerjakan siswa dikoreksi dan dikembalikan dengan feeddback yang terstruktur paling lambat sebelum pembelajaran unit materi ajar berikutnya., dan 5) Memberi kesempatan kepada siswa yang belum berhasil menguasai materi ajar berdasarkan hasil analisis tes untuk mengikuti remidial di luar jam pembelajaran [11].

Keuntungan pembelajaran dengan modul antara lain berfokus pada kemampuan individual siswa yang memungkinkan siswa untuk dapat belajar mandiri sesuai kemampuannya masing-masing, adanya kontrol terhadap hasil belajar melalui standar kompetensi yang dimuat dalam modul dan siswa dapat mengetahui keterkaitan pembelajaran dengan hasil yang akan diperolehnya. Sedangkan kelemahan modul adalah : penyusunan modul yang baik membutuh-kan keahlian tertentu, sulit menentukan penjadwalan dan kelulusan karena setiap siswa menyelesaikan modul dalam waktu yang berbeda-beda.

\section{B. Pembelajaran dengan Multimedia Interaktif}

Multimedia interaktif adalah suatu multimedia yang dilengkapi dengan alat pengontrol yang dapat dioperasikan oleh pengguna sehingga dapat memilih apa yang dikehendaki untuk proses selanjutnya, bertanya, dan mendapatkan jawaban yang mempengaruhi komputer untuk mengerjakan fungsi selanjutnya [8]. Multimedia interaktif dapat dibuat dalam beberapa bentuk, salah satunya adalah CD (Compact Disk) interaktif, yang merupakan $\mathrm{CD}$ program pembelajaran yang mencakup berbagai sumber yang terintegrasi dalam perintah-perintah dalam sebuah sistem berbasis komputer. Multimedia $\mathrm{CD}$ interaktif menggunakan media offline berupa CD ROM (Read Only Memory) yang terintegrasi dengan komputer. Hal ini membuat CD interaktif lebih menguntungkan dibandingkan multimedia online seperti internet, karena tidak membutuhkan koneksi internet diwaktu pembelajaran.

Multimedia interaktif terdiri dari beberapa elemen, yaitu teks, grafik dan gambar, suara, video dan animasi. Multimedia interaktif dapat dibuat dalam beberapa model, seperti tutorial, drill and practice, simulasi, permainan dan percobaan atau eksperimen [8-9]. Model multimedia yang digunakan dalam penelitian ini adalah model tutorial yang dikemas dalam bentuk CD interaktif. Model tutorial dipilih karena materi pelajaran KKPI yang dijadikan objek dalam penelitian ini lebih banyak berisikan praktek dengan kompetensi dasar mengoperasikan software presentasi.Tutorial juga dilengkapi latihan-latihan yang akan meningkatkan pemahaman siswa tentang materi yang diberikan.

Pembelajaran dengan CD interaktif dilakukan dalam tiga tahap, yaitu tahap persiapan, tahap pelaksanaan dan tahap tindak lanjut [12]. Dalam 
penelitian ini pembelajaran KKPI dengan CD interaktif juga dilakukan dalam tiga tahap, yaitu 1) Tahap persiapan meliputi : a) Membagikan CD interaktif kepada siswa sebelum pembelajaran dimulai, b) Menyiapkan segala peralatan yang dibutuhkan untuk pembelajaran, yang mencakup hardware dan software. 2) Tahapan pelaksanaan dilakukan dengan langkah-langkah : a) Tempat duduk siswa diatur sesuai dengan meja computer yang tersedia, b) Menjelaskan tujuan yang akan dicapai, topik yang akan dipelajari dalam $C D$ interaktif, c) Siswa disuruh membuka CD interaktif sesuai dengan topik yang telah ditentukan, d) Siswa disuruh mengerjakan tugas yang diberikan, dan e) Memberikan kesempatan kepada siswa untuk bertanya serta membimbing siswa yang belum mengerti tentang materi yang diberikan. 3) Tahap tindak lanjut dilakukan dengan langkah-langkah : a) Memberikan penguatan tentang materi, b) Melakukan evaluasi melalui tes sesuai topik yang ditentukan, c) Memeriksa hasil tes siswa, dan d) Memberikan umpan balik berdasarkan hasil tes siswa.

Multimedia interaktif memiliki beberapa keunggulan dibandingkan media lain, antara lain : 1) Siswa dapat belajar mandiri sesuai dengan kemampuan dan kecepatannya masing-masing, 2) Siswa dapat memilih materi dalam CD interaktif secara bebas, 3) Iklim belajar lebih efektif bagi siswa yang lambat belajar tapi juga dapat memacu efektifitas belajar bagi siswa yang cepat, 4) Desain tampilan multimedia interaktif yang menarik akan meningkatkan gairah serta minat belajar siswa, 5) Multimedia interaktif memungkinkan terjadinya interaksi dan umpan balik antara siswa dengan media, 6) Siswa dengan mudah dapat mengulang materi secara bebas dan mudah, 7) Skor hasil belajar secara otomatis dapat ditampilkan melalui program, sehingga siswa dapat mengetahui hasil belajarnya sendiri.

\section{Hasil Belajar}

Hasil belajar adalah segala sesuatu yang menjadi wujud dari usaha seseorang setelah memperoleh pengalaman belajar/ setelah ia mempelajari sesuatu [1]. Hasil belajar dibagi dalam tiga ranah, yaitu ranah kognitif, ranah afektif dan ranah psikomotor. Ranah kognitif berkaitan dengan kemampuan berpikir. Ranah afektif berkenaan dengan sikap atau nilai, sedangkan ranah psikomotor berhubungan dengan keterampilan atau kemampuan bertindak.

Ada tiga faktor yang mempengaruhi hasil belajar siswa, yaitu faktor dari dalam diri siswa itu sendiri, faktor dari luar dan faktor pendekatan pembelajaran [2]. Dalam penelitian ini, faktor pendekatan pembelajaran dijadikan objek untuk memperbaiki hasil belajar siswa, yaitu dengan menerapkan pendekatan pembelajaran yang berbeda, yang terdiri dari pembelajaran dengan menggunakan modul dan pembelajaran dengan menggunakan multimedia interaktif. Strategi pembelajaran divariasikan dengan memperhatikan faktor internal siswa yang dipresentasikan melalui kreativitas siswa dalam belajar.

Hasil belajar siswa dapat diketahui melalui proses penilaian, yaitu proses sistematis meliputi pengumpulan informasi (angka atau deskripsi verbal), analisis, dan interpretasi untuk mengambil keputusan [1]. Penilaian hasil belajar harus memenuhi kriteria berikut : valid, reliabel, berfokus pada kompetensi, menyeluruh, objektif dan mendidik [1].

Penilaian hasil belajar siswa SMK dapat dilakukan dalam berbagai bentuk, yang mencakup penilaian unjuk kerja, penilaian sikap dan penilaian tertulis [1]. Penilaian unjuk kerja merupakan penilaian yang dilakukan untuk menilai kinerja siswa dalam praktek. Penilaian sikap dilakukan untuk menilai sikap siswa di dalam proses pembelajaran, sedangkan penilaian tertulis dilakukan untuk mengukur kemampuan kognitif siswa yang dapat dilakukan dalam bentuk tes objektif atau tes subjektif.

Proses pembelajaran KKPI di SMKN 2 Bukittinggi dilaksanakan secara teori dan praktek. Oleh sebab itu, penilaian hasil belajar siswa juga dilakukan dalam kedua proses pembelajaran tersebut, yang mencakup : penilaian unjuk kerja, penilaian sikap dan penilaian tertulis. Penilaian unjuk kerja dan penilaian sikap dilakukan untuk pelajaran praktek, sedangkan penilaian tertulis dalam bentuk objektif dilakukan untuk pelajaran teori.

\section{Kreativitas}

Kreativitas adalah kemampuan untuk membuat kombinasi baru berdasarkan data atau unsur-unsur yang ada dimana hasil yang diciptakan tidak selalu hal-hal yang baru, tetapi juga dapat berupa gabungan dari hal-hal yang sudah ada sebelumnya [3]. Kreativitas siswa dipengaruhi oleh faktor dari dalam diri sendiri dan dari luar. Faktor yang mempengaruhi kreativitas siswa dari luar salah satunya adalah strategi pembelajaran. Guru harus bisa melaksanakan pembelajaran yang dapat meningkatkan kreativitas siswa.

Kreativitas siswa dapat dikelompokan atas kreativitas kognitif (aptitude) dan kreativitas sikap atau perasaan (nonaptitude) [3]. Kreativitas 
kognitif atau disebut juga kemampuan berpikir kreatif meliputi : keterampilan berpikir lancar, berpikir luwes, berpikir orisinal dan keterampilan memerinci, sedangkan ciri-ciri sikap meliputi : rasa ingin tahu, sifat imajinatif, merasa tertantang oleh kemajemukan, sifat berani mengambil resiko dan sifat menghargai.

Kreativitas siswa yang diukur dalam penelitian ini adalah kemampuan berpikir kreatif. Salah satu instrumen yang dapat digunakan untuk mengukur kreativitas kognitif adalah Torrance Tests of Creative Thinking (TTCT), yang terdiri dari dua set tes, yaitu tes verbal dan tes figural. TTCT merupakah salah satu bentuk baku tes berpikir kreatif yang sederhana serta memiliki validitas dan reliabilitas yang tinggi [4]. Berdasarkan keunggulannya, maka digunakanlah TTCT bentuk figural dalam penelitian ini. TTCT bentuk figural terdiri dari tiga bentuk soal, yaitu membuat gambar, melengkapi gambar yang belum selesai dan membentuk gambar dari lingkaran yang digunakan untuk mengukur kemampuan berpikir kreatif, yang mencakup kelancaran (fluency), keluwesan (flexibility), keaslian (originality), dan kemampuan memperinci (elaboration) [5].

\section{Metode Penelitian}

Penelitian ini menggunakan pendekatan kuantitatif dengan metode quasi eksperiment (eksperimen semu) dengan variabel terikat hasil belajar dan variabel bebas strategi pembelajaran dan kreativitas siswa. Variabel strategi pembelajaran terdiri dari pembelajaran menggunakan multimedia interaktif dan pembelajaran menggunakan modul cetak, sedangkan variabel kreativitas dikelompokan atas kreativitas rendah dan kreativitas tinggi.

Penelitian diawali dengan memilih dua kelas sampel, yaitu satu untuk kelas eksperimen dan satu untuk kelas kontrol yang dipilih dengan teknik cluster porpusive sampling. Sampel dipilih dari populasi 14 kelas siswa kelas XI di SMK N 2 Bukittinggi. Kedua kelas diberi tes tertulis awal untuk melihat homogenitas kedua kelas, supaya dapat dibandingkan. Tahap berikutnya dilakukan tes kreativitas dengan menggunakan TTCT figural B. Hasil tes kreativitas digunakan untuk mengelompok-kan kreativitas siswa ke dalam dua kelompok, yaitu siswa kreativitas tinggi dan siswa kreativitas rendah.

Kedua kelas sampel diberi pembelajaran KKPI dengan kompetensi dasar "mengoperasikan software presentasi" dengan perlakuan yang berbeda. Kelas kontrol menggunakan modul cetak yang disusun oleh tim kelompok kerja guru KKPI SMK N 2 Bukittinggi, sedangkan kelas eksperimen menggunakan $\mathrm{CD}$ interaktif yang berisi materi "mengoperasikan software presentasi". Dalam proses pembelajaran, posisi siswa diatur sesuai dengan kelompok kreativitasnya.

Pembelajaran dilakukan dalam delapan kali pertemuan yang mencakup pemberian materi dan tes hasil belajar. Tes hasil belajar dilakukan dalam dua bentuk, yaitu tes tertulis berupa soal pilihan ganda digunakan untuk mengukur hasil belajar bidang kognitif dan tes praktek untuk mengukur hasil belajar bidang afektif dan psikomotorik. Setiap dua kali pertemuan dilakukan tes tertulis dengan materi tes disesuaikan dengan materi yang telah diberikan sebelumnya. Pada pertemuan ketujuh dilakukan tes tertulis dengan menggunakan instrumen yang telah diujicobakan kepada kelas lain untuk melihat validitas, reliabilitas, daya beda, taraf kesukaran dan keberfungsian distraktor dari instrumen tersebut. Data hasil belajar siswa diperoleh dengan menggabungkan hasil tes tertulis dengan hasil tes praktek.

Data hasil penelitian dianalisis berdasarkan desain faktorial $2 \times 2$ dengan analisis varian dua arah dan uji t menggunakan software SPSS yang didahului dengan uji prasyarat analisis.

\section{Hasil dan Pembahasan}

Sebelum melakukan uji hipotesis dengan analisis varian dua arah, dilakukan uji persyaratan analisis yang mencakup normalitas dengan metode Kolmogorov Smirnov (Uji K-S) dan uji homogenitas dengan metode Levene Statistic. Ringkasan hasil uji prasyarat analisis diuraikan dalam Tabel 1. Semua pengujian dilakukan pada taraf signifikasi 0.05 .

Tabel 1 menunjukkan bahwa data K-S pada semua kelompok perlakuan lebih besar dari nilai taraf signifikasi 0,05. Dapat disimpulkan bahwa semua data pada semua kelompok perlakuan berdistribusi normal. Hasil uji homogenitas dengan metode Levene Statistic diperoleh nilai Levene 1,385 dengan skor signifikasi 0,256. Karena skor signifikasi lebih besar dari taraf signifikasi, sehingga dapat disimpulkan bahwa data homogen dan dapat dilakukan uji hiopetesis dengan analisis varian dua arah dan uji t. 
Tabel 1. Ringkasan hasil uji persyaratan analisis

\begin{tabular}{|c|c|c|c|c|c|c|c|c|}
\hline \multirow{2}{*}{$\begin{array}{l}\text { Kelas/ } \\
\text { Perlakuan }\end{array}$} & \multirow{2}{*}{$\begin{array}{c}\text { Jumla } \\
\text { h } \\
\text { Siswa }\end{array}$} & \multicolumn{4}{|c|}{ Kreativitas } & \multicolumn{3}{|c|}{ Hasil Belajar } \\
\hline & & Kelompok & mean & \multicolumn{2}{|c|}{ K-S } & mean & \multicolumn{2}{|c|}{ K-S } \\
\hline \multirow{2}{*}{$\begin{array}{l}\text { Eksperimen/ } \\
\text { CD interaktif (A1) }\end{array}$} & 16 & Tinggi (B1) & 80,12 & \multirow{2}{*}{0,51} & 0,46 & 87,15 & \multirow{2}{*}{0,55} & 0,50 \\
\hline & 16 & Rendah (B2) & 58,00 & & 0,56 & 80,72 & & 0,62 \\
\hline \multirow{2}{*}{$\begin{array}{l}\text { Kontrol/ } \\
\text { Modul cetak (A2) }\end{array}$} & 16 & Tinggi (B1) & 82,19 & \multirow{2}{*}{0,58} & 0,57 & 85,21 & \multirow{2}{*}{0,65} & 0,62 \\
\hline & 17 & Rendah (B2) & 60,82 & & 0,74 & 74,73 & & 0,52 \\
\hline
\end{tabular}

Ada empat hipotesis yang diuji dalam penelitian ini. Hasil uji hipotesis dengan analisis varian dua arah menggunakan software SPSS diringkas dalam Tabel 2 dan hasil uji t hipotesis diringkas dalam Tabel 3.

Tabel 2. Ringkasan hasil analisis varian dua arah

\begin{tabular}{|l|c|c|c|c|c|}
\hline Variabel & $\begin{array}{c}\text { Jumlah } \\
\text { kuadrat }\end{array}$ & $\mathrm{dk}$ & $\begin{array}{c}\text { Rerata } \\
\text { kuadrat }\end{array}$ & $\mathrm{F}$ & Sig \\
\hline $\begin{array}{l}\text { Strategi } \\
\text { Belajar } \\
\text { (A) }\end{array}$ & 246,62 & 1 & 246,62 & 16,74 & 0,000 \\
\hline $\begin{array}{l}\text { Kreativitas } \\
\text { (B) }\end{array}$ & 1162,11 & 1 & 1162,11 & 78,88 & 0,000 \\
\hline $\begin{array}{l}\text { Interaksi } \\
\text { (A x B) }\end{array}$ & 66,39 & 1 & 66,39 & 4,51 & 0,038 \\
\hline
\end{tabular}

Hipotesis pertama menyatakan bahwa terdapat perbedaan hasil belajar KKPI siswa kelas XI yang diajar menggunakan multimedia interaktif (A1) dengan yang diajar menggunakan modul cetak (A2).

Hasil analisis varian dua arah pada Tabel 2 menunjukkan bahwa variabel strategi belajar (A) memiliki nilai $F_{h i t u n g} 16,74$ dengan probabilitas signifikasi $(\mathrm{Sig}=0,000)$ lebih kecil dari nilai taraf signifikasi $(0,05)$, sehingga dapat disimpulkan bahwa hasil belajar siswa yang menggunakan multimedia interaktif(A1) lebih baik dibandingkan dengan hasil belajar siswa yang menggunakan modul cetak (A2). Signifikasi perbedaan hasil belajar kedua kelas (A1 x A2) dapat dilihat dari hasil uji thipotesi yang terdapat dalam Tabel 3.

Hasil uji t hipotesis pertama (A1 x A2) dalam Tabel 3 memiliki nilai $t_{\text {hitung }}=2,81$ dengan probabilitas signifikasi $(\mathrm{Sig}=0,007)$ lebih kecil dari nilai taraf signifikasi $(0,05)$, sehingga dapat disimpulkan bahwa hipotesis pertama diterima atau dengan kata lain terdapat perbedaan yang signifikan antara hasil belajar KKPI siswa yang diajar dengan multimedia interaktif (A1) dengan hasil belajar KKPI siswa yang diajar dengan modul cetak (A2). Data ini menunjukkan bahwa strategi pembelajaran yang digunakan ikut mempengaruhi hasil belajar siswa.

Tabel 3. Ringkasan hasil uji thipotesis

\begin{tabular}{|l|c|c|}
\hline \multicolumn{1}{|c|}{ Variabel } & thitung & Sig \\
\hline A1 x A2 & 2,81 & 0,007 \\
\hline (A1B1) x (A2B1) & 1,22 & 0,232 \\
\hline (A1B2) x (A2B2) & 5,19 & 0,000 \\
\hline
\end{tabular}

Hipotesis kedua menyatakan bahwa terdapat perbedaan hasil belajar siswa berkreativitas tinggi yang diajar menggunakan media interaktif (A1B1) dengan siswa berkreativitas tinggi yang diajar menggunakan modul cetak (A2B1).

Hasil analisis varian dua arah pada Tabel 2 menunjukkan bahwa variabel kreativitas (B) memiliki nilai $\mathrm{F}_{\text {hitung }}=78,88$ dengan probabilitas signifikasi ( $\mathrm{Sig}=0,000)$ lebih kecil dari nilai taraf signifikasi $(0,05)$, sehingga dapat disimpulkan bahwa hasil belajar KKPI siswa berkreativitas tinggi (B1) lebih baik dari hasil belajar siswa yang berkreativitas rendah (B2). Data ini menunjukkan bahwa kreativitas siswa ikut mempengaruhi hasil belajar siswa. Signifikasi perbedaan hasil belajar siswa berkreativitas tinggi yang diajar dengan multimedia interaktif (A1B1) dengan hasil belajar siswa berkreativitas tinggi yang diajar dengan menggunakan modulcetak (A2B1) dapat dilihat dari hasil uji t yang terdapat dalam Tabel 3 .

Hasil uji t variabel (A1B1) x (A2B1) pada Tabel 3 memiliki nilai $t_{\text {hitung }}=1,22$ dengan probabilitas signifikasi $(\mathrm{Sig}=0,232)$ lebih besar dari nilai taraf signifikasi $(0,05)$, sehingga dapat disimpulkan 
bahwa hipotesis kedua ditolak atau tidak terdapat perbedaan yang signifikan antara hasil belajar siswa berkreativitas tinggi yang diajar menggunakan media interaktif (A1B1) dengan siswa berkreativitas tinggi yang diajar menggunakan modul cetak (A2B1) walaupun ratarata hasil belajar siswa berkreativitas tinggi yang diajar menggunakan media interaktif $(87,15)$ lebih tinggi dibandingkan dengan rata-rata hasil belajar siswa berkreativitas tinggi yang diajar dengan modul $(85,21)$, seperti yang terdapat pada Tabel 1 . Perbedaan rata-rata hasil belajar kedua kelompok ini sebesar 1,94 diartikan tidak berbeda secara signifikan. Hal ini menunjukkan bahwa siswa berkreativitas tinggi akan tetap memiliki hasil belajar yang baik walaupun diberi strategi pembelajaran yang berbeda. Hal ini disebabkan oleh siswa yang berkreativitas tinggi memiliki keterampilan berpikir kreatif yang mencakup keterampilan berpikir lancar, luwes dan orisinal.

Hipotesis ketiga menyatakan bahwa terdapat perbedaan hasil belajar KKPI siswa berkreativitas rendah yang diajar menggunakan media interaktif (A1B2) dengan siswa berkreativitas rendah yang diajar menggunakan modul cetak (A2B2).

Hasil analisis varian dua arah pada Tabel 2 menunjukkan bahwa variabel Kreativitas (B) ikut mempengaruhi hasil belajar KKPI siswa, seperti yang diuraikan pada hipotesis kedua. Perbedaan antara hasil belajar siswa berkreativitas rendah yang diajar dengan multimedia interaktif (A1B2) dengan siswa berkreativitas rendah yang diajar menggunakan modul cetak (A2B2) dapat dilihat dari hasil uji t yang terdapat pada Tabel 3. Hasil uji t untuk variable (A1B2) x (A2B2) memiliki nilai $t_{\text {hitung }} 5,19$ dengan probabilitas signifikasi (Sig $=0,000)$ lebih kecil dari taraf signifikasi $(0,05)$, sehingga dapat disimpulkan bahwa hipotesis ketiga diterima, dengan kata lain terdapat perbedaan yang signifikan antara hasil belajar siswa berkreativitas rendah yang diajar dengan media interaktif (A1B2) dengan hasil belajar KKPI siswa berkreativitas rendah yang diajar dengan modul (A2B2). Perbedaan yang signifikan antara hasil belajar siswa berkreativitas rendah pada kedua kelas perlakuan dapat dilihat dari rata-rata hasil belajar siswa pada Tabel 1 dengan perbedaan sebesar 5,98.

Hasil ini menunjukkan bahwa multimedia interaktif lebih efektif meningkatkan hasil belajar siswa berkreativitas rendah dibandingkan modul cetak. Hal ini disebabkan oleh keunggulan yang dimiliki multimedia interaktif itu sendiri. Multimedia interaktif yang terdiri dari gabungan beberapa media yang ditampilkan secara menarik akan memperjelas penyajian bahan ajar, sehingga mudah dipahami bagi semua golongan siswa.

Hipotesis keempat menyatakan bahwa terdapat interaksi antara strategi pembelajaran menggunakan multimedia interaktif atau modul dengan kreativitas siswa dalam mempengaruhi hasil belajar KKPI siswa.

Hasil analisis varian dua arah dalam Tabel 2 menunjukkan bahwa variabel interaksi (A x B) memiliki nilai $F_{\text {hitung }}=4,51$ dengan probabilitas signifikasi $(\mathrm{Sig}=0,038)$ lebih kecil dari nilai taraf signifikasi(0.038), sehingga dapat dinyatakan bahwa hipotesis diterima atau dengan kata lain terdapat interaksi antara strategi pembelajaran menggunakan multimedia interaktif atau modul dengan kreativitas siswa dalam mempengaruhi hasil belajar KKPI. Interaksi antara strategi pembelajaran menggunakan multimedia interaktifatau moduldengan kreativitas siswa dalam mempengaruhi hasil belajar siswa dapat dilihat dari hasil belajar siswa pada setiap kelompok yang disajikan pada Tabel 1 dan Gambar 1 .

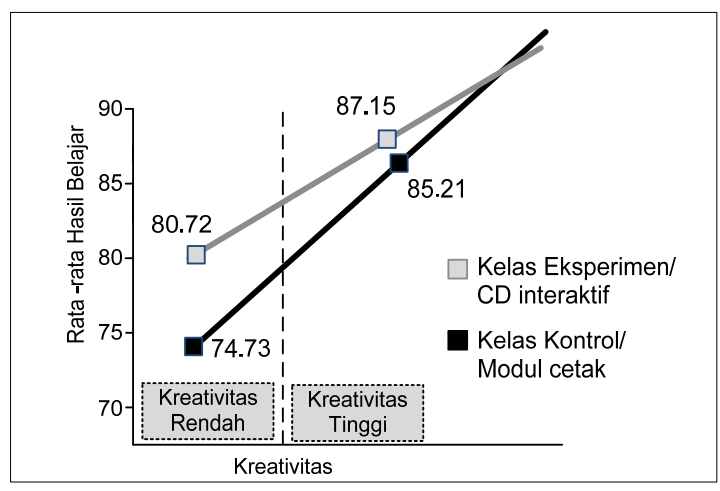

Gambar 1. Rata-rata hasil belajar siswa pada kedua kelas perlakuan berdasarkan kelompok kreativitas siswa

Tabel 1 dan Gambar 1 menunjukkan bahwa hasil belajar siswa yang diajar dengan multimedia interaktif (A1) lebih baik dibandingkan hasil belajar siswa yang diajar dengan modul (A2), baik pada kelompok siswa berkreativitas tinggi (B1) maupun pada kelompok siswa berkreativitas rendah (B2). Hal ini menunjukkan bahwa multimedia interaktif lebih efektif meningkatkan hasil belajar siswa dibandingkan dengan modul. Data ini juga menunjukkan bahwa strategi pembelajaran ikut mempengaruhi hasil belajar siswa. Gambar 1 juga menunjukkan bahwa penggunaan multimedia interaktif pada kelas eksperimen dapat meningkatkan hasil belajar siswa berkreativitas rendah secara signifikan sebesar 5,98 poin. Hasil belajar siswa berkreativitas tinggi yang 
diajar dengan multimedia interaktif juga lebih baik dibandingkan hasil belajar siswa berkreativitas tinggi yang diajar dengan modul, walaupun tidak memiliki perbedaan yang signifikan.

Semua data ini menunjukkan bahwa adanya interaksi strategi pembelajaran dengan kreativitas siswa dalam mempengaruhi hasil belajar siswa. Suatu interaksi terjadi ketika efek faktor yang satu tergantung pada faktor lainnya dalam mempengaruhi sesuatu [13]. Sehingga dapat disimpulkan bahwa masing-masing faktor (strategi pembelajaran dan kreativitas siswa) dalam penelitian ini saling tergantung satu sama lainnya dalam mempengaruhi hasil belajar KKPI siswa.

\section{KESIMPULAN}

Berdasarkan hasil penelitian dan analisis yang telah dilakukan dapat disimpulkan bahwa terdapat perbedaan yang signifikan antara hasil belajar KKPI siswa yang diajar menggunakan multimedia interaktif dengan hasil belajar siswa yang diajar dengan modul cetak, dimana hasil belajar siswa yang menggunakan multimedia interaktif lebih baik dibandingkan hasil belajar siswa yang diajar dengan modul cetak.

Hasil belajar KKPI siswa berkreativitas tinggi yang diajar dengan multimedia interaktif lebih baik dibandingkan hasil belajar siswa berkreativitas tinggi yang diajar dengan modul cetak, walaupun tidak terdapat perbedaan yang signifikan

Terdapat perbedaan yang signifikan antara hasil belajar KKPI siswa berkreativitas rendah yang diajar menggunakan multimedia interaktif dengan hasil belajar siswa berkreativitas rendah yang diajar dengan modul cetak, dimana hasil belajar siswa berkreativitas rendah yang diajar menggunakan multimedia interaktif lebih baik dibandingkan hasil belajar siswa berkreativitas rendah yang diajar dengan modul cetak.

Terdapat interaksi antara strategi pembelajaran yang menggunakan multimedia interaktif atau modul dengan kreativitas siswa dalam mempengaruhi hasil belajar KKPI siswa kelas XI di SMK N 2 Bukittinggi.

\section{DAfTAR PUSTAKa}

[1] Nana Sudjana. 2005. Penilaian hasil proses belajar mengajar. Bandung: Remaja Rosdakarya

[2] Muhabbibin, S. 2003. Psikologi Belajar. Jakarta: Grafindo Persada

[3] Munandar, U. 2009. Pengembangan Kreativitas Anak Berbakat. Jakarta :Rineka Cipta
[4] Thomson, G. dan Lordan, M. 1999. "A review of creativity principles applied to engineering design". Journal of Process Mech Engineering, 2(13), 17-31.

[5] Torrance, E. P. 1966. The Torrance Tests of Creative Thinking Norms Technical Manual Research Edition-Verbal Tests, Forms $A$ and BFigural Tests. Princeton, NJ: Personnel Press.

[6] Sutjiono.2005. Media Pembelajaran. Jakarta : Rineka Cipta

[7] Jyotsna Dikshit. 2013."Pedagogic Effectiveness of Print, Interactive Multimedia, and Online Resources : A Case Study of IGNOU". International Journal of Instruction, 6 (2), 1-13.

[8] Mayer, R. 2009. Multimedia Learning: Second Edition. New York : Cambridge University Press.

[9] Andrizal dan Ahmad Arif. 2017. "Pengembangan media pembelajaran interaktif pada sistem elearning Universitas Negeri Padang," INVOTEK: Jurnal Inovasi, Vokasional dan Teknologi, 17(2), 1-10.

[10] Andi Prastowo. 2010. Panduan Kreatif Membuat Bahan Ajar Inovatif. Yogyakarta: DIVA Press

[11] Dikmenjur. 2008. Teknik penyusunan modul. Jakarta : Depdiknas.

[12] Heinich, R, dkk. 1996. Instructional Media and Technology for Learning. New Jersey : Prentice Hall, Inc.

[13] Irianto, Agus. 2004. Statistik, Konsep Dasar dan Aplikasinya, Jakarta: Prenada Media

\section{Biodata Penulis}

Reni Fitrisia, Lahir di Candung pada tanggal 3 September 1982. Pendidikan terakhir program Magister Pendidikan Teknologi Kejuruan, Fakultas Teknik, Universitas Negeri Padang dengan kosentrasi Pendidikan Teknik Informatika. Semenjak tahun 2009 bekerja sebagai guru mata diklat KKPI dan simulasi digital di SMK N 2 Bukittinggi.

Nizwardi Jalinus, Lahir di Palembang pada tanggal 22 Agustus 1952. Menyelesaikan program sarjana Pendidikan Teknik Mesin di Universitas Negeri Padang pada tahun 1978 dan program Doktor Pendidikan Vokasi pada tahun 1998 di University of Tasmania, Australia. Saat ini menjadi Guru besar di Fakultas Teknik Universitas Negeri Padang. 